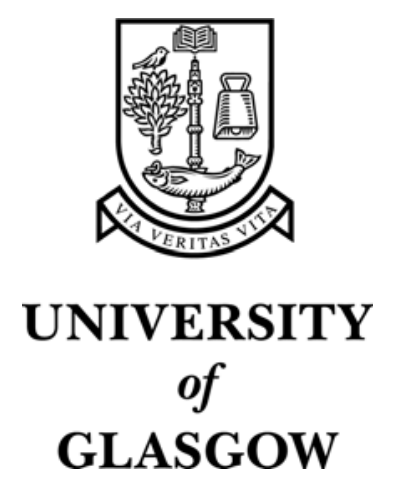

Beattie, V. and Davie, E. (2006) Theoretical studies of the historical development of the accounting discipline: a review and evidence. Accounting, Business and Financial History 16(1):pp. 1-25.

http://eprints.gla.ac.uk/3053/ 
Theoretical Studies of the Historical Development of the Accounting Discipline:

A Review and Evidence

Vivien Beattie* and Elizabeth Davie**

* Professor of Accounting, University of Glasgow

** Lecturer in Accounting, University of Stirling

Address for correspondence

Prof. Vivien Beattie

Department of Accounting and Finance

University of Glasgow

71 Southpark Avenue

Glasgow

G12 8LE

Tel. 01413306855

Fax 01413304442

Email V.Beattie@accfin.gla.ac.uk

Acknowledgments:

This paper has benefitted greatly from the helpful comments of Professor Bill McInnes, Professor Segun Wallace and two anonymous reviewers. Thanks to Gillian MacIver and Jacky Pierpoint for assistance with the empirical mappings. 


\title{
Theoretical Studies of the Historical Development of the Accounting Discipline: A Review and Evidence
}

\begin{abstract}
Many existing studies of the development of accounting thought have either been atheoretical or have adopted Kuhn's model of scientific growth. The limitations of this thirty-five year old model are discussed. Four different general neo-Kuhnian models of scholarly knowledge development are reviewed and compared with reference to an analytical matrix. The models are found to be mutually consistent, with each focusing on a different aspect of development. A composite model is proposed. Based on a hand-crafted database, author co-citation analysis is used to map empirically the entire literature structure of the accounting discipline during two consecutive time periods, 1972-81 and 1982-90. The changing structure of the accounting literature is interpreted using the proposed composite model of scholarly knowledge development.
\end{abstract}

Keywords: accounting theory; author co-citation analysis; history of accounting thought; scholarly knowledge development; theory closure; theory groups. 


\section{INTRODUCTION}

An understanding of the development of scholarly accounting knowledge can benefit accounting scholars in three main ways. First, by identifying the causes and consequences of change, we potentially gain insights into the role of accounting practice and education in accounting research. The relationship between research and practice remains a particular concern (Baxter, 1988; Dyckman, 1989; Lee, 1989 and 1990; Bricker and Previts, 1990; and Bloom et al., 1994). Second, it has long been recognised that a number of different theories exist within the accounting discipline. This situation has attracted concern over the lack of theory closure (AAA, 1977) and produced a variety of characterisations of the main theoretical perspectives (e.g., Chua, 1986). An understanding of the development of accounting knowledge can be expected to facilitate an explanation of the current structure of the discipline, thereby moving forward the debate concerning the relationship between different theoretical perspectives (e.g., Gaffikin, 1988; 2003). Third, it can be argued that such an understanding will benefit educators, serving as a pedagogic device for the teaching of accounting theory. In particular, an understanding of the development of scholarly accounting knowledge offers a rationale for students for what can seem very disparate strands of research.

Throughout the accounting literature, there exist numerous references to the impact of a variety of factors on the development of accounting thought. These factors include individuals, groups, institutions, journals, new ideas (in the form of concepts, methods or theories), the accountancy profession, and external social, economic, and cultural factors (see, for example, McRae (1974); Cox et al. (1976); Dyckman and Zeff (1984); Brown and Gardner (1985a; 1985b); Brown et al. (1987; 1989); Bricker (1988); and Beattie and Ryan (1989: 1991). The reflexive nature of accounting knowledge is also noted. This form of growing 'disciplinary self-awareness' is viewed as a sign of a discipline’s maturity (Borgman, 1990: 12). There are, however, few studies in the area of 'development of accounting thought' which make explicit use of any theoretical model as a basis for interpretation. Furthermore, the only model which has been employed is the Kuhnian model of knowledge growth (e.g., Wells, 1976; AAA, 1977; and Lee, 1993). Although this model is undoubtedly of major significance, its applicability with respect to the discipline of accounting has been questioned. The uncritical adoption of Kuhn's thesis can also restrict historical self-understanding, as has happened with respect to other social sciences (Peterson, 1981). Surprisingly, the relevance to the accounting discipline of major theoretical advances which have occurred in the field of scholarly knowledge development during the thirty-five years 
since Kuhn’s ideas were first published (Kuhn, 1962) has not been investigated.

The general aim of the present paper is to provide a framework which can support richer interpretations of the development of the accounting discipline than those which have previously been offered. It has four specific objectives: (i) to review four neo-Kuhnian models of scholarly knowledge development; (ii) to develop a composite model which is capable of providing a rich understanding of the processes by which theories and associated theory groups emerge, grow, and decline; (iii) to map empirically the major theories and theory groups in the discipline of accounting; and (iv) to interpret the changing structure of the discipline using the composite model. The composite model incorporates theoretical insights which have not previously been compared and contrasted.

The remainder of this paper is structured as follows. Section two outlines Kuhn's model and reviews the studies in accounting which have employed Kuhn's model to analyze the discipline and discusses the limitations of this model. In section three, four different neo-Kuhnian models of scholarly knowledge development are described, critically appraised, and integrated. Section four generates, using author co-citation analysis, empirical maps of the intellectual structure of accounting which reveal the theoretical and social groups within accounting's scholarly community. These maps are described and interpreted in section five with reference to the composite model of scholarly development. The final section summarises and concludes.

\section{PRIOR THEORETICAL STUDIES OF DEVELOPMENT IN THE ACCOUNTING DISCIPLINE}

To date, theoretical studies of development in the accounting discipline have used exclusively Kuhn's model of knowledge growth (1962 and 1970). Kuhn was instrumental in the development of the modern philosophy of science in which science is relativised to some extent. Scientific knowledge (and other specialised non-science bodies of knowledge) therefore becomes contingent upon social, cultural, and historical processes. This permitted the integration of three earlier approaches to the study of scientific knowledge development into a unified area of study termed the sociology of scientific knowledge (Knorr-Cetina and Mulkay, 1983: 2-3; Woolgar, 1988: 23). ${ }^{2}$

The model of scholarly knowledge development proposed by Kuhn is characterised by periods of 
continuous growth with discontinuities. Kuhn distinguishes between mature and immature bodies of scholarly knowledge (disciplines). Immature disciplines are characterised by competing schools of thought and are described as pre-paradigmatic. The concept of a 'paradigm', which is fundamental to Kuhn's thesis, unfortunately was not defined clearly or consistently by Kuhn (1962). The related concept of a 'disciplinary matrix', which incorporates symbolic generalisations, beliefs in models, shared values and exemplars, was introduced by Kuhn in the second edition of his book (1970: 189). Mature disciplines were argued to experience cyclical progression through periods of continuous growth (normal science) and discontinuities (revolutions). During periods of normal science, everyone works within the same disciplinary matrix, extending and developing the known (described as 'puzzle-solving'). Revolutions begin with the recognition of anomalies within the current disciplinary matrix. There follows a period of insecurity and then the development of alternative sets of ideas. New schools of thought are identified and, finally, one school emerges as dominant, providing the new disciplinary matrix for the next period of normal science.

Early studies of the development of accounting thought have tended to focus on financial accounting, since this was the subject area that dominated the journal literature until recent decades. $^{3}$ Wells (1976) was the first to provide a comprehensive analysis of the development of accounting thought in terms of the pattern of revolutionary development described by Kuhn. He identifies the historical cost model, developed during the 1930s and 1940s, as being the first disciplinary matrix in accounting. In subsequent decades, anomalies in the model emerged, particularly its failure to incorporate changes in asset prices and the monetary unit. By the 1960s, insecurity had given way to crisis and a range of alternatives to the historical cost model were proposed (e.g., Edwards and Bell, 1961; Chambers, 1966). These writings on asset measurement alternatives typify the 'golden age of a priori research in accounting', described and criticised by Nelson (1973: 4; Gaffikin, 2003).

Wells argues, however, that this research fulfilled a critical role in the selection of a new disciplinary matrix by identifying alternative schools of thought. A process of shifting allegiances determines which alternative will emerge as the new disciplinary matrix, although at the time of writing Wells believed that it was too early to identify which one this would be. It should be noted that Wells does acknowledge the existence of non-income measurement proposals, such as research into share price movements, however he does not integrate this into his analysis. 
In contrast, the independently conducted analysis by the AAA (1977) is more wide-ranging. It identifies three broad theoretical approaches current at that time: classical (including early income measurement); decision-usefulness (including early behavioural accounting research and market-based accounting research); and information economics. It is argued, again using Kuhn (1970) as the authority, that 'the process of theorising in accounting may be more revolutionary than evolutionary' (AAA, 1977: 41). Each of these currently competing paradigms is seen to specify a different domain for the application of accounting theory, which reflects basic differences in 'world-views'. These world-views comprise beliefs and premises which cannot be proved or disproved in a logical sense. Thus we should not expect that theoretical closure will occur (AAA, 1977: 47-48).

However, Peasnell (1978) is critical of the AAA's application of Kuhn's ideas, arguing that Kuhn's 'paradigms' are not necessarily in competition with each other, and pointing out that the classical and decision-usefulness paradigms complement and interact. Peasnell also argues that Kuhn is concerned with the development of science rather than a service activity such as accounting. Laughlin (1981) also makes this latter criticism.

Despite the criticisms of Peasnell (1978) and Laughlin (1981), more recent discussions of the development of accounting thought continue to adopt a Kuhnian interpretation which, at best, offer only a partial explanation of the development of accounting thought. Some writers discuss the discipline as a whole (e.g., Glautier (1983) and Cushing (1989)), while others focus on specific sub-areas of knowledge (e.g., Cleaver and Evans, 1991; Lee, 1993; and Mouck, 1993). ${ }^{4}$

In his long-run historical analysis, Glautier (1983) suggests that, since antiquity, accounting has in fact been characterised by several rounds of paradigm consensus and revolution. His tests confirm the hypothesis that the concentration of political power leads to accounting systems which focus on control, while diffuse power results in a variety of systems each with different objectives.

Cushing (1989) identifies the double-entry bookkeeping model as the first dominant paradigm in accounting, with the discipline entering a crisis stage about 1960. He argues that, in the U.S., government intervention into the accounting process, in the form of standard-setting regulation, represented the first stage of crisis. Four fundamental anomalies emerged which could not be 
resolved within the existing paradigm: the arbitrary nature of allocations; the politicization of accounting; the impossibility of rational choice among accounting alternatives; and the role of accounting scholars as the providers of 'excuses'. This crisis led many accounting scholars to abandon the study of fundamental accounting issues and instead adopt a scientific approach to research which draws upon the paradigms of other disciplines (p.31). Thus, the domain of the accounting discipline widened and new theory groups formed. Two influential reports on higher education in US business schools called for the transfer of knowledge and methods from underlying disciplines, causing business schools to adopt the scientific method (Dyckman and Zeff, 1984: 231-2; Williams, 2003: 252).

Three studies have focused on specific sub-areas of knowledge. Cleaver and Evans (1991) employ elements from the Kuhnian framework in their analysis of the gap between management accounting research and practice. They argue that the separation of a research discipline from immediate external demands is a sign of the discipline's maturity. They also argue that the increasingly specialist orientation of the journal literature is a sign of the professionalization of the research process, which also signifies maturity. Lee (1993) argues that during the past 30 years cash flow reporting has developed through the various revolutionary stages proposed by Kuhn. Mouck (1993) employs a Kuhnian framework to argue that the transition in financial reporting theory from an 'economic income perspective' to an 'informational perspective' is not a revolution (as it is described by Beaver (1981)), but rather a normal science expansion of the economics paradigm. This view seems to be supported by Beaver, who notes that there is currently renewed interest in the 'measurement perspective', although without the original normative flavour (1996: 117).

To summarise, there exists no consensus as to whether accounting is pre-paradigmatic or mature, and (if mature) the identity of current paradigms and whether the discipline is in a state of crisis or normal activity. Thus, there is agreement neither on the nature of the specific correspondence between Kuhn's stages of disciplinary development and the development of accounting thought, nor even on the fundamental issue of their applicability.

The present paper argues that this disagreement arises partly because no formal empirical analysis is offered in support of alternative interpretations of accounting's development and partly because of the inherent limitations of Kuhn's framework. Kuhn's concept of a paradigm has proved very attractive and has motivated debates in many disciplines about whether the 
discipline has identifiable paradigms and whether revolutions have occurred. However, the concept of a paradigm has been shown to be highly problematic (Masterman, 1970) and such debates are no longer considered to be fruitful (Barnes, 1982: 120). Scholars in other social science disciplines now argue strongly against the uncritical appropriation of Kuhn's model of mature science (e.g., Peterson, 1981: 19 and 22-3).

The value of Kuhn's work lies in his recognition that social, cultural, institutional, and external factors can all be involved in scholarly knowledge development. However, although Kuhn acknowledges the influence of social factors on scientific beliefs and their assessment, his analysis emphasises cognitive factors. A more complete account of scholarly knowledge development therefore requires the addition and integration of a thorough sociological analysis (Barnes, 1982: 14).

\section{NEO-KUHNIAN MODELS OF SCHOLARLY KNOWLEDGE DEVELOPMENT}

In the second edition of his book, Kuhn (1970) emphasised the central role of the social structure of science and the need for empirical research in this area, making reference to the potential value of studies of scientific communication. These studies concern the social stratification of science, and establish, empirically, that the social system of science is highly stratified and dominated by a relatively small number of individuals (Price, 1961 and 1963; Cole and Cole, 1973). This class structure of scholarly communities is derived both from the nature of their product (i.e., writings) and from the nature of the system of production which is driven by scholars' 'urge to accumulate something analogous to capital' (Harre, 1986: 9). Under the institutionalised process of evaluation, scholars are motivated to seek the rewards of high reputation which is gathered through (i) publication in the formal literature; and (ii) subsequent citation by other authors. Thus, a citation can be viewed as a unit of capital, functionally equivalent to a unit of currency.

Studies of scientific communication generated further theoretical insights which led, in turn, to the development of different models of scholarly knowledge development. Four such models are identified here: the 'four stage model'; the 'branching model'; the 'interest model'; and the 'closure model'. These models have not previously been compared and contrasted. Each is now described in turn. The final sub-section summarises the strengths and weaknesses of each model and offers a synthesis. 


\section{The four stage model}

The four stage model proposed by Mullins (1973) developed from studies of communication networks within research areas (i.e., social structures and formal literature structures). The theoretical social construct of the 'invisible college' was introduced by Price (1963) to refer to the informal affiliation of scientists who share common interests but who are located at different institutions and therefore might live some distance from one another (Lievrouw, 1990: 62). This concept was subsequently investigated empirically by Crane (1972), in her study of the growth of communication networks within two research areas. Based on these and other empirical studies of social structure, Crane (1972) and Mullins (1973) both identify four types of social relationship which can exist between scholars: coauthorship; trusted assessorship; colleagueship; and apprenticeship. Coauthorship involves an extremely close association where two or more scholars engage in collaborative research and trusted assessorship refers to informal discussions with selected individuals about ongoing research. Colleagueship exists between scholars who work at the same institution and apprenticeship refers to the student/teacher relationship.

Mullins (1973) presents a model of scholarly knowledge development which incorporates these conceptual insights regarding social relationships and is also consistent with the empirical evidence regarding cognitive structures which was available at the time. Mullins' model comprises four stages, with each stage being characterised by empirically demonstrable social and cognitive characteristics. The four stages are: normal; network; cluster; and speciality. A brief outline of each stage follows. The normal stage displays little social organisation and the literature is produced by a few people at scattered institutions. The emergence of a recognisable new research area requires the appearance of an 'intellectual success', i.e., an orientation which can be distinguished from the parent discipline's existing modes of rationalisation. This success normally marks the end of this first stage, and may include a critique of the parent discipline's current work. At this point the author(s) of these successes become(s) the intellectual leader(s) of the group.

The transition to the network stage occurs when a small number of other researchers are attracted to these intellectual successes. Social ties begin to form as these people come to focus on each other as trusted assessors, and movement between institutions can occur to form colleagueship relations. If there is continued intellectual success, then this 'thickening' of the communication network continues as students are recruited and apprenticeship links formed. At this stage, it is common to find both a programmatic statement (outlining the issues to be addressed and the 
methods to be used by the group) and an organisational leader (who draws colleagues and students together, often to a particular institution).

The transition to cluster stage is frequently marked by the publication of research resulting from the consensus. The communication network becomes larger and denser, with clusters of students and colleagues growing around the leading figures of the group at one (or perhaps a few) institutions and co-authorship links becoming established. At this stage, large quantities of research are produced and intellectual successes continue with strong theoretical connections between specific pieces of work. Secondary materials (review articles and textbooks) and work which is critical of the group appear at this stage, and specialised conferences and journals may be set up by the organisational leader(s). The parent discipline's reaction to the new group now emerges, with the group either being accepted as a valid new perspective and absorbed within the discipline, or being rejected and isolated from the discipline. In this latter case, the group may die, may gradually replace the parent, or may become the growth point of a new speciality (or even a new discipline).

The final transition, from cluster to speciality, occurs inevitably as students become successful themselves and are promoted to jobs at other institutions. As ties become weakened, and intellectual successes no longer occur, the work which has been done must be institutionalised if the cluster is to be ultimately successful. This involves the organisational leader(s) in establishing journals, departments and positions for the new speciality. Members of the group start to make ties into other research areas (Mullins, 1973: 17-33). ${ }^{5}$

Importantly, group development may terminate at any stage in this process, if any of the key properties identified above fail to emerge. In addition, the group remains open to influence from other research areas at all stages. This occurs because research areas have no natural boundary, and the membership of networks can overlap considerably. The importance of Mullins' model lies in the fact that it deals with both social and cognitive aspects, and addresses explicitly the issues of group formation and change. However, it is essentially a static model.

\section{The branching model}

The branching model, developed by Mulkay (1975) and Mulkay et al. (1975), is based on a number of detailed case studies of scientific development which were undertaken by a group of U.K. researchers, and were motivated partly by the apparent deficiencies of functionalist analysis, 
viz. failure to incorporate either deviant behaviour or cognitive aspects. These case studies explore the impact of cognitive, social, and technical factors on the emergence and growth of specific research areas. The study of radio astronomy by Edge and Mulkay (1976) is typical of such studies, many of which are reviewed by Mulkay (1979: 73-90).

Several major insights emerged from these case studies. First, it became clear that scientific knowledge has a tacit component which cannot be made explicit, and which is most effectively communicated through informal interaction. Second, available knowledge and techniques can be interpreted in a variety of ways, even in situations where the theoretical framework is well established. ${ }^{6}$ Third, consensus regarding the meaning of results is achieved via negotiation through both formal channels of communication and informal interaction. This closure may involve the highly selective presentation of evidence and/or the misrepresentation of opposing arguments. Fourth, knowledge-claims which are based on radically different assumptions to those held presently by a scientist are forcefully resisted. Finally, the intellectual commitments held by a scientist can be influenced directly by their social location (Mulkay, 1979: 90-92).

Based on these case studies, Mulkay and his associates develop the branching model of scientific development which can be said to incorporate the earlier models of Kuhn (1962) and Mullins (1973). They argue that Kuhn's model is a special case, since it excludes the consideration of discoveries which are compatible with the existing orthodoxy, yet do not advance it and hence generate new research areas. This is the basis of their model of 'growth by branching'. It is presented as a three stage model - exploration, growth, and decline and disbandment - with the growth stage encompassing both the exponential (network) and the linear (cluster) growth stages of Mullins’ model.

The significance of the branching model is its explicit consideration of the forces which give rise to the emergence and decline of new research areas. These forces are generated by the evaluation and reward system in science (Merton, 1973), which motivates researchers working in areas which are experiencing a decline in the significance of current results to attempt to initiate a new research area. However, the branching model is deficient in two key respects. First, it fails to incorporate the influence of factors external to the system and, second, it fails to consider adequately the mechanisms through which consensus and closure are achieved. 
The interest model emerged from the 'strong programme' of research on the sociology of scientific knowledge developed by Bloor (1976) and Barnes (1977). ${ }^{7}$ In common with the branching model, it is based on empirical case studies of scientific development. It emphasises particularly the role of external factors of a social, political, and cultural nature, thereby overcoming one of the main deficiencies of the branching model (whose focus is on internal factors). The interest model claims that the social organisation of science, and of society at large, affects the content of scientific knowledge (a view consistent with more recent interpretations of Marx). The strong form of this view is that not only the production of new ideas, but also the processes by which these ideas are accepted or rejected, can be influenced by social factors via the relationship between belief and social position. Social position characterises interests and experiences, which in turn constrain the set of 'appropriate’ beliefs, i.e., beliefs which justify and enhance a group's privileges. Thus, actors’ self-interested positions reflect external factors.

This approach has been used by MacKenzie (1981) to study the content of statistical theory, particularly the eugenics movement, in the period 1865-1930. His study provides convincing evidence that interests should be part of any complete account of science.

Watts and Zimmerman's (1979) influential economic analysis of the determination of accounting theory is also based on the 'interests' of actors, although they emphasise the individual, rather than group, self-interest arguments. They argue that the demand for accounting theories is created by a political process where self-interested individuals compete to achieve wealth transfers. Accounting procedures are capable of effecting such transfers, which creates a demand for accounting theories which buttress the desired wealth transfers. Since individual interests differ, a variety of accounting theories are required. This characterisation gives rise to the labelling of accounting theories as 'excuses'. The supply of accounting theories of this type is ensured via the academic community's evaluation and reward mechanisms. These mechanisms are viewed by Watts and Zimmerman as being moderated crucially by the consumers of accounting theories (accounting firms, bureaucrats, and corporate managers), since such groups provide a large proportion of research and consulting funds. Thus, academics will direct their efforts towards current controversies in accounting, with those who produce research which is supportive of the position of vested interests being the ones who receive rewards. They conclude that the appearance of accounting theories in the literature will, in general, lag political issues.

This conclusion is challenged by Lowe et al. (1983), who argue that accounting theories can also 
lead the political interest, if they are generated in response to a 'societal dynamic need', with further theories emerging once the issue becomes politically active (1983: 34). Peasnell and Williams (1986) also challenge Watts and Zimmerman's view, on the grounds that the academic reward system does not provide incentives to provide excuses.

Watts and Zimmerman marginalise the role of intellectual factors, highlighting instead the particular role played by outside groups (especially the accounting profession) in the evaluation and reward structure of the academic accounting community. However, Watts and Zimmerman do acknowledge that academic evaluation and criticism creates incentives for researchers to be 'consistent' (1979: 287).

\section{The closure model}

The second identified deficiency of the branching model concerned its failure to specify consensus and closure mechanisms in sufficient detail. Under both the functionalist and Marxian theories of stratification in science, those individuals who accumulate the highest reputation form an intellectual elite who exercise authority to achieve consensus and closure. However, neither theory specifies adequately the mechanisms involved. Within the discipline of sociology as a whole, this type of limitation of the two prevailing general social theories had already become apparent. During the 1970s, this resulted in the development of closure theory by Collins and Parkin (see, for example, Collins (1979) and Parkin (1974)). This theory drew upon the Weberian concept of social closure, which focuses attention on the mechanisms of monopolisation and exclusion (Murphy, 1988: 15).

'Closure' is the process of using power to enhance/defend a group's share of rewards/resources. Two types of closure strategy have been identified: exclusionary and usurpationary. Exclusionary closure involves the exercise of power in a downward direction. In this situation, a higher group secures its advantages by closing off the opportunities of a lower group. This action has the potential to provoke from the lower group usurpationary strategies which are designed to erode the advantages of higher groups. General societal forms of closure are based on property, educational credentials, race, etc.

Murphy (1988) was the first to explicitly suggest that closure theory (a general social theory) could be applied to scholarly communities. ${ }^{8}$ In such an application, distinct forms of scholarly closure can be identified, which are based on particular types of knowledge and which relate to 
academic rewards. When closure theory is applied to scholarly communities, the higher groups can be said to comprise the dominant perspectives of the discipline. The observed structure of the discipline at any point in time can, therefore, be viewed as the result of previous strategies of exclusionary closure and usurpation. It is the successful exercise of usurpationary strategies which results in the special case of revolutionary change described by Kuhn.

\section{A composite model}

Each of the four models discussed above focuses upon different aspects of the development of scholarly knowledge. These aspects can be classified as relating to three dimensions of scholarly knowledge development, as follows:

(i) source of change (e.g., internal cognitive, internal social, or external);

(ii) stage of group change (e.g., formation, growth, closure); and

(iii) degree of concern with the processes of change.

Although none of the four models discussed covers the full range of all dimensions, each does (explicitly or implicitly) recognise their existence.

Using this classificatory framework, the key features of each model can readily be established. The four stage model is particularly concerned with identifying the cognitive and social properties of research areas (i.e., theories and theory groups) throughout their growth. However, by focusing on properties it is essentially a comparative-static, structural model. The branching model is also concerned with intellectual and social sources of change, focusing on the forces which cause the formation and closure of research areas. The model integrates the operation of the scholarly evaluation and reward system and the role of scholarly migration into the explanation of scholarly knowledge development. The interest model's particular strength clearly lies in its explicit examination of external factors, particularly those which affect the nature of actors' self-interest. Finally, the closure model provides a specific explanation of the mechanisms of closure, thereby considering some of the dynamic processes involved.

These points are summarised in Figure 1, from which it is evident that, in combination, the four different four models have the potential to provide a rich explanation of scholarly knowledge development. 
The composite model proposed in the present paper offers a potentially useful general framework within which the development of accounting thought can be interpreted (and within which extant studies can be re-interpreted). To illustrate its potential value, an interpretation of the entire accounting discipline is presented. To undertake this interpretation, the initial task is to identify research areas (which comprise theories and theory groups) within the accounting discipline. The method adopted is to use empirical analysis, rather than analyze purely sociometric relationships or rely on the subjective perceptions of an individual. However, no claim is made that the empirical maps derived here have any preferred, logical status over alternative views of the discipline’s structure.

Scholarly communication, which is the fundamental process of research, has both social and cognitive aspects. The 'invisible college' concept describes the social aspects of scholarly communication. Cognitive aspects are traced through published research documents, which are the formal output of scholarly activity and the formal channel for the communication of ideas. The conventions surrounding the attribution of credit for ideas to other scholars, i.e., bibliographic citation, permit the ‘intellectual linkages’ between papers to be revealed. In a series of independent studies by Price and Garfield, it was discovered that the analysis of these citations successfully captures the literature structure which, in turn, closely reflects the cognitive and social structures of the research area (Price, 1963; Garfield, 1979). ${ }^{9}$

Empirical maps of the accounting discipline's literature are developed using citation analysis of selected literature over two consecutive time periods. The particular form of citation analysis used (author co-citation analysis) is, potentially, an especially useful method of identifying research areas, since the resultant empirical map of the intellectual structure of accounting can reveal the theoretical and social groups within accounting's scholarly community. Author cocitation analysis has been used successfully to study a number of fields outside of accounting, for example, social indicators (White, 1981 and 1983), information science (White and Griffith, 1981a), judgment and decision research (White and Griffith, 1981b), studies of science, technology and society (SSTS) (White and Griffith, 1982), macroeconomics (McCain, 1983) and medical informatics (Andrews, 2003). Longitudinal analyses of structural change are less common and more recent (e.g., macroeconomics (McCain, 1984), new causal theory and ethnomethodology (Hopkins, 1984), genetics (McCain, 1986), MIS (Culnan, 1987) and information science (White and McCain, 1998). 
The method has three principal advantages. First, the method takes people as the basic unit of analysis, which is consistent with the central role played by people in the synthesised model's account of the processes of change. Second, by examining two consecutive time periods, the changing structure of the accounting literature is uncovered, thus permitting the dynamics of theory group growth and decline to be inferred. Third, empirical literature maps of this type provide a useful benchmark against which to evaluate a variety of historical accounts of the development of accounting thought.

Moreover, it has been argued that an important contribution to accounting thought research could be made by 'identifying the interrelationships between individuals' and 'concepts' and 'tracing the changes in these relationships as they impact the development of knowledge over time' (Previts et al., 1990: 141). In author co-citation analysis, prominent authors have been shown to serve as 'concept markers' (McCain, 1983) and are plotted in intellectual space. The resulting empirical map reveals the relationships among prominent authors and theory groups, and these relationships play an important part in consensus and closure mechanisms.

Author co-citation analysis locates authors with similar ideas close to each other, and places authors whose ideas are linked (through co-citation) with many other authors near the centre of the map. Thus, densely interconnected authors form clusters corresponding to theory groups. This form of visual display has a number of specific advantages. First, the axes generally describe the broad dimensions of the discipline's research orientation or scholarly style. Second, central and peripheral theory groups within the discipline are identified, as are the strengths of connections among them. Third, the map reveals who is central and who is peripheral, both to the discipline as a whole and to individual theory groups. In addition, 'bridger theorists', who provide a link between two distinct theory groups, are identified (Freidheim, 1978). Finally, a longitudinal comparison of maps can indicate the way in which theory groups have evolved through time. In a review of studies which have constructed such maps for other disciplines, White (1990) concluded that author co-citation analysis can successfully uncover intellectual structures.

Citation analysis can take three principal forms (basic citation analysis, document co-citation, and author co-citation). Basic citation analysis examines the number of times a document, author, or journal is cited, interpreting the number as a measure of 'impact'. Co-citation analysis is 
concerned with the number of times a document cites both $\mathrm{X}$ and $\mathrm{Y}$. The basic premise is that the strength of intellectual linkage is positively related to the co-citation count. Therefore if $\mathrm{X}$ and $\mathrm{Y}$ are treated as points in Euclidean space, and co-citation counts as the inverse of distance, then maps can be created using the technique of multidimensional scaling. This visual representation can be further enhanced by using clustering techniques to identify groups of highly related units.

Co-citation analysis was originally developed in situations where $\mathrm{X}$ and $\mathrm{Y}$ represented documents (Small, 1973; Small and Griffith, 1974). However, the analysis has since been extended to apply to authors (White, 1981 and 1983; White and Griffith, 1981a, 1981b and 1982). Author cocitation analysis is concerned with the number of times a document cites both author $\mathrm{X}$ and author Y, i.e. a particular author pair. The co-citation counts of one author with all other authors (i.e. the counts from multiple author pairs) determine the location of that author in relation to all other authors in intellectual space. In author co-citation maps, the proximity of points reflects similarities between authors as perceived by many citers. In this context, each author represents an oeuvre, i.e., a body of writings by the same author. There are only a small number of influential researchers whose writings fall into more than one theory group (e.g., Kinney). Although all authors do not map isomorphically with concepts, an approximate one-to one mapping is sufficient for the purposes of this paper. As authors operate at a higher level of aggregation than individual documents, this form of co-citation analysis permits an entire discipline to be mapped with relatively few author names (White and Griffith, 1982: 257) since prominent authors act as 'concept markers'. 10

The key stages in the creation of an author map relate to author selection, data collection, and analytic procedures. It is essential to identify a diverse set of authors on which to base the analysis, since this set defines the scholarly landscape being mapped (McCain, 1990). However, it is not necessary that the author set provides an exhaustive list of important authors; it is sufficient to use an author set which is representative of major research areas. There was no restriction to a specific type of accounting knowledge, such as financial accounting.

The procedure most commonly adopted by prior studies is to select from a current textbook of the field those authors who have more than a certain number of page references in the index. Then, using the online bibliographic database Social Science Citation Index (SSCI), counts are obtained of the number of papers in the journal literature which contain at least one reference to each 
author in a specified pair of authors’ names.

In the present study, however, this approach was rejected due to two major limitations of the SSCI. First, the journal set covered by the SSCI is heavily biased towards leading US journals and hence US authors. Second, the SSCI allows citations to be retrieved only under the firstnamed author. Studies have shown that both the incidence of co-authorship and the average number of co-authors has been growing in the accounting discipline (Hasselback, et al., 2000: 84; Beattie and Goodacre, 2004: 28). For this reason, it was decided to undertake to hand-build a citations database using a journal set that gives a balanced country coverage of the most research-active countries of the time period. The number of journals in existence has been growing rapidly in recent years. Zeff (1996) identifies only seven accounting journals in publication in 1972, rising to 77 by 1996 . The nine journals selected ${ }^{11}$ were:

US journals:

Accounting Review

Journal of Accounting Research

Journal of Accounting and Economics

UK journals:

Accounting and Business Research

Journal of Business Finance and Accounting

Accounting, Organizations and Society

Australian journals:

Abacus

Accounting, Auditing and Accountability Journal

Mixed country connections:

Critical Perspectives on Accounting. ${ }^{12}$

Using Microsoft Access $^{\mathrm{TM}}$, a database was designed to capture all cited authors from the individual papers in all issues of these nine journals during the period 1972-1990. The time period analysed covers a nineteen year period during which empirical research using economic and psychology theory really got underway and ends around about the time when research using more critical and interdisciplinary approaches was becoming more established (the emergence of AAAJ and CPA). Several of the journals were not in existence for the full period. New journals come into existence as research areas reach a certain stage of development, and their inclusion properly reflects the way in which the discipline was developing during the period. ${ }^{13}$ Citations from a total of 429 journal issues and 4,211 papers gave rise to 122,485 citations to 25,635 cited authors (including all second and subsequent 
named authors). Table 1 shows that start year of each journal, its main focus and the number of papers analysed from each journal. Initially, all authors with 85 or more citations were selected and a preliminary alphabetical listing was scanned and name ambiguities resolved (typically the use of a different number of initials). ${ }^{14}$ Non-accountants were included as it is known that accounting is an applied social science discipline that draws upon theories and methods from a number of different foundation disciplines (McRae, 1974; Beattie and Goodacre, 2004: 13-14). This resulted in an author set of 142. Then, for each consecutive time period (1972-1981 and 1982-1990) and for each of the 10,011 author pairs (i.e., n(n1)/2), a count was made of the number of papers which cited the two authors at least once. These raw co-citation counts were transferred into an Excel spreadsheet in the form of a matrix.

[Table 1 about here]

Subsequent data processing comprised five steps. First, following McCain (1989), diagonal cell values, which can often be spuriously exaggerated due to self-citations were treated as missing values. Second, authors who were neither cited nor co-cited with reasonable frequency were deleted, since in this situation co-citation counts can be unstable with authors failing to cluster meaningfully when mapped (White, 1986; Culnan, 1986). To be able to visually discriminate the authors on the mapping, and also to take account of the maximum number of variables limit in SPSS, the final number of authors was reduced to 59 for the first period and 62 for the second period. ${ }^{15}$ Thirty-seven authors were common to both author sets. The author sets are shown in Table 2. Third, the raw co-citation matrix was downloaded into SPSS and converted into a correlation matrix. Fourth, nonmetric multidimensional scaling was used to generate maps of points (representing authors) in n-dimensional space. ${ }^{16}$ Finally, the map was visually enhanced using cluster analysis to reveal groups and sub-groups. ${ }^{17}$

[Table 2 about here]

The resulting empirical maps of the intellectual structure of accounting during each time period are shown in Figures 2 and 3 respectively. The number of major theory groups uncovered is three in the first period, rising to five in the second time period.

[Figures 2 and 3 about here]

\section{DESCRIPTION AND INTERPRETATION}

1972-81

In this period, three major clusters appear to exist, some with nested sub-clusters. Sub-clusters 
are shown within clusters to capture the similarities, as well as the differences, between groupings and reflect the key details from close visual inspection of the dendrogram produced by the cluster analysis. Most can be associated readily with theory groups or research areas of the time. Accounting's traditional school of thought concerns principles and postulates, normative income theory, and the standard-setting process and appears at the top of the map, noticeably not occupying a central position (cluster 1$){ }^{18}$ The sub-cluster at the right hand side (cluster 1a, including Chambers and Sterling) focuses on income theory. The other two subclusters (1b and 1c) are particularly concerned with policy-making (including the economists Arrow and Baumol), with some individuals at the left-hand side also having interests in managerial/behavioural issues (i.e. Horngren, Birnberg, Feltham). A number of authors are located at the edge of one cluster and close to another. These are 'boundary authors', in that their work falls into more that one area, e.g., Ijiri, Zeff and Feltham.

The second major cluster has two sub-clusters, a very dense one at the bottom right-hand side (cluster 2a) and a more diffuse one occupying a more central position on the map as a whole (cluster 2b). The dense core (including Ball, Brown, Watts and Beaver) can best be described as concerning empirical research relating to policy-making and the stock market. ${ }^{19}$ This sub-cluster also includes a considerable number of finance researchers, such as Fama, Scholes, Miller, Linter, Sharpe, Roll and Gordon. The more diffuse sub-cluster (including Abdel-Khalik, Rappaport, Ronen and Zimmerman) can be thought of as generalists with interests in both standard-setting and the stock market. It is clear that, during this time period, market-based empirical research achieved an equal level of importance to the discipline as normative income theory, as both of these sub-clusters are approximately equidistant from the origin of the map. Closest to the origin, however, lie the policy-making/generalist sub-clusters.

The cluster which is most peripheral appears on the left-hand side of the map (cluster 3) has been labelled 'behavioural'. It includes organisational theorists and psychologists with an interest in human information processing (Cyert, March and Simon). Finally, there are three authors who are shown as lying outside any of the main clusters. ${ }^{20}$ These authors have links to more that one main theory group (for example Kinney has written on audit judgment and also empirical marketbased accounting research).

$1982-90$

The map of this period is similar to the previous one in a number of respects, indicating a high 
degree of stability in the intellectual development of accounting. There are now, however, five major clusters; the clusters having undergone a substantial degree of change as the theory groups have evolved.

Two sub-clusters now appear as separate clusters, but in approximately the same location: the income theory cluster, which now includes the UK author Peasnell, (cluster 1), and the dense empirical cluster. It is likely that the development of this cluster reflects the introduction of economics-based agency theory to the accounting literature in the late 1970s. This cluster is clearly representative of positive accounting theory and market-based accounting research (cluster 2). It contains 23 authors (out of 62), none of which is UK-based. The generalists and those with a primary interest in policy issues (whether theoretical or empirical) now merge to form a distinct central cluster (numbered cluster 1/2). This cluster contains the economists Jensen and Meckling, whose major work discusses agency theory in relation to the firm. The UK author Lee, who has written on a wide variety of topics including income and value measurement, user needs, now appears in this group. Copeland, Dopuch and Jensen serve as boundary authors between cluster $1 / 2$ and cluster 2. The 'behavioural' cluster, which was peripheral and rather small in the 1972-81 period, has grown and fractured into two major clusters, each now with a much clearer focus. Simon, Swieringa and Libby, now joined by Ashton and Weick and the psychologists Einhorn and Hogarth, form a separate major cluster (3a) that has moved towards the left-hand side of the map. No UK authors remain in this group. A large part of this research area is concerned with auditing. Auditing research remained undeveloped until statistical techniques and psychological models were applied to it during the 1970s and 1980s.

Perhaps the most dramatic change in the map as a whole, however, relates to the remainder of this early behavioural cluster. Hopwood (a UK author and founder editor of Accounting, Organizations and Society) and March (both from cluster 3 in the previous period), are joined by Horngren, Livingstone and Feltham (from cluster 1 in the previous period) and Cooper (an author of UK origins) and others to form a management/critical cluster (numbered 3b). The writings of Habermas, Foucault and Marx form the philosophical basis of the critical research area. While some individuals in this cluster might be thought of as clearly 'management' researchers and others as clearly 'critical' researchers, they are being cited together. Other authors in the cluster write in both areas (e.g. Hopwood). This cluster is (relatively) well-represented by U.K. authors, whereas it is U.S. authors who dominate the remainder of the map. The existence of 
geographically-based competing research elites is consistent with the findings of Lukka and Kasanen (1996), who distinguish a dominant U.S. elite from an emerging, mostly European elite.

In this time period, there are four authors who are shown as lying outside any of the main clusters. These authors tend to have links to more that one main theory group, and so fail to cluster meaningfully.

The major proponents of a number of research areas are identified by Mattessich (1991). Those authors whom he mentions include Hopwood for managerial accounting, Cooper and Hopwood for organisational accounting, Cooper for critical perspectives, Libby and Ashton for experimental behavioural accounting, and Watts and Zimmerman for positive accounting theory. These authors are each located in the empirical map for the period 1982-90, with their position generally corresponding closely to Mattessich’s views.

\section{Interpretation using composite model}

The growth of the empirical/positive accounting theory group over the two time periods illustrates the importance of social relationships in the evolution of theory groups. A key aspect of this group in the period 1972-81 is the link with the University of Chicago. Ball, Beaver, Benston, Brown (P), Lev, and Watts all hold doctorates from Chicago, with Beaver, Benston, and Gonedes being current or ex-faculty members (Hopwood, 1992). This can be explained using the four stage model discussed above: the social ties of colleagueship and apprenticeship begin to form during the network stage of theory group development due to movement between institutions and the recruitment of students. These internal social links facilitate the research area's growth.

By the period 1972-81, this theory group would appear to have evolved to the cluster stage of the four stage model, since the communication network is large and dense, due to clusters of students and colleagues developing around the leading individuals at one, or a few, institutions. By the later time period, Ball, Benston and Watts move to Rochester, while Beaver moves to Stanford, and thus these institutions also become centres for this theory group, forming an invisible college of scholars.

A number of the authors fulfilled the role of intellectual and/or organisational leaders for individual theory groups, by producing successful new writings (which mark the beginning of the 
network stage of theory development), programmatic statements (which occur during the network stage), and/or by setting up specialist conferences and journals (which generally occurs during the cluster stage).

These empirical literature maps also provide a useful context within which to evaluate the role of journals in the development of theory groups in accounting. The creation of specialised journals is characteristic of the cluster and specialty stages of Mullins' model and provides an outlet for the research area's writings. This is crucial to growth, as recent studies have documented the existence of an elite group of researchers on the editorial boards of six major accounting research journals, who could potentially force closure to accounting knowledge production (Lee, 1997). In the earlier map period, the emergence in 1963 of the Journal of Accounting Research, a journal dedicated to empirical research in accounting, is likely to have assisted in the growth of the empirical theory group. The position of Davidson with respect to this group and the income theory/standard setting group is of significance. He lies within the generalist/standard setting cluster in the later period, and can be interpreted as a bridger theorist. Whilst most of Davidson's early work was in the former area, he was also the first editor of the Journal of Accounting Research Supplements, which published the proceedings of an annual conference dedicated to empirical research in accounting (Davidson, 1984, p. 285).

During the later map period, the distinctive perspectives of the author clusters become more clearly defined as theory groups reach the later stages of development. The emergence of the Journal of Accounting and Economics in 1979, edited jointly by Watts and Zimmerman, can be associated with the development of a group of positive accounting theorists, dedicated to the application of economic theory to accounting issues. In addition, the emergence of Accounting, Organizations and Society in 1976, edited by Hopwood, has supported the continuing development of 'behavioural' accounting in three distinct directions: (i) human information processing, (ii) management accounting, and (iii) organisational and social perspectives. The founding of Auditing: A Journal of Practice and Theory in 1981/82 further supported the development of human information processing research. More recently, the launch of Management Accounting Research in 1990 supported research in this area, while the launch of Critical Perspectives on Accounting in 1990, jointly edited by Tinker and Cooper, has facilitated the development of critical approaches to accounting. This specialist nature of most new journals, which reflects the particular orientation of the various 'colleges' in academic life, has been noted by a former editor of the British Accounting Review (Gray, 1993: 105). 
The nature and extent of interdisciplinary borrowing is also apparent when interpreting the maps' axes. Whilst the labelling of the map axes is most readily apparent in the later map, the underlying dimensions of accounting's intellectual structure appear to have remained quite stable. The vertical axis can best be interpreted as representing different methodological approaches to accounting research, and hence different methods used in accounting research. The bottom extreme of the map reflects a positivist methodology and the use of quantitative empirical methods, whereas the top extreme of the map reflects the use of normative theory and qualitative methods. Turning to the horizontal axis, the left-hand side appears broadly to reflect behavioural aspects of accounting, while the right-hand side reflects technical aspects of accounting. Consequently, the horizontal axis in Figures 2 and 3 can be thought of as representing the range of research specializations in terms of their foundation disciplines. The discipline of accounting has become more open to influence from other disciplines, with interdisciplinary borrowing of both theories and analytical methods. The disciplines which these specialties draw on range from psychology and management at the left-hand side, through sociology and political science, mathematics/decision science/game theory, to economics and finance at the extreme right-hand side.

Thus, the accounting discipline is now characterised by the existence of multiple theory groups, where originally only one existed. The original accounting theory was the normative, historical cost, income determination model of Paton and Littleton (1940) (Ryan et al., 1992). This 'fragmentation' is attributable to growth in the domain of accounting research. New questions about accounting began to be asked, and these were answered from a variety of methodological stances, using theories and methods from a range of other disciplines (Peasnell, 1978). This evolution of the accounting discipline is consistent with the branching model, in which new discoveries which are consistent with the existing orthodoxy generate new research areas. Kuhn's model of revolutionary change thus becomes a special case.

A number of factors were instrumental in the development of new theories. First, the income theory/standard-setting group was experiencing a decline in the significance of its results, due to the problems identified by Cushing (1989). Consequently, researchers seeking reputational capital were motivated to look for new 'discoveries'. The crucial role played by the academic evaluation and reward system is recognised explicitly by the branching model. This role has intensified in the U.K. as a result of the periodic Research Assessment Exercise, which evaluates 
and rewards institutions (www.rae.ac.uk).

Key external influences on the nature of subsequent discoveries were: developments in other disciplines, which were applied to accounting; greater data availability; and changes in the financial reporting environment (in particular, new accounting standards which, in turn, reflect broader societal changes) (Beaver, 1996). A critical factor in the growth phase of the embryonic theory groups has been journal access. The closure model highlights the fact that an editorial elite can exclude writings of the new theory group, hence constricting (or even preventing) the group's development. This exclusionary strategy is, however, ineffective if the new groups are able to set up new specialist journals which gain high status among the academic community.

The standard-setting theory group has, however, retained a fairly central position within the discipline, despite the apparent declining significance of results. This is perhaps because it is academic research into financial reporting issues that are, arguably, of most value to the accountancy profession and to the consumers of accounting theories generally. These users provide (at least in the U.S.) the majority of research funding. This influence is captured by the interest model.

\section{SUMMARY AND CONCLUSIONS}

This paper has developed a general framework for understanding scholarly knowledge development which incorporates insights gained since the 1960s. This framework combines aspects from four neo-Kuhnian models which have not previously been compared and related. It also encompasses the analysis of both the structures and processes of scholarly knowledge, in terms of sources of change and stages of change. This composite model, which offers a more explicitly sociological analysis than Kuhn's model, contributes to the historical literature on the development of accounting thought by providing a comprehensive framework for understanding the development of the discipline.

Based on a hand-crafted database, author co-citation analysis is used to empirically map the entire literature structure of the accounting discipline during two consecutive time periods, 197281 and 1982-90. These maps offer an empirically grounded, consensus view and an explicit visual representation of the discipline. The composite model was used to interpret the changing structure of the theoretical and social groups within the accounting discipline over the period 
1972-90. This model accommodates a wide range of influences upon the development of the discipline. In particular, the impact of the following factors in the evolution of theory groups was highlighted: social relationships; intellectual and/or organisational leaders; journals; research from disciplines outside accounting; the academic evaluation and reward system; external influences; and the interests of funding providers.

The empirical maps of the discipline will also be of value to accounting educators. Modern learning theory suggests that individuals learn by building and revising 'cognitive maps'. Explicit visual representations of knowledge, in the form of cognitive maps, can facilitate deep learning, which results in conceptual understanding. The maps can assist undergraduate students taking an advanced accounting theory course, research students and academic faculty in the early stages of their career in their understanding of the different strands of accounting research and their relationship to each other.

The empirical maps which are constructed inevitably simplify and abstract. Whilst this is acceptable for the purpose of the paper, their limitations must be borne in mind. First, authors are used as concept markers, yet in a few cases individual authors represent multiple perspectives (although these multiple perspectives tend not to be concurrent, which reduces the problem) An example is Hopwood (A), who moved from budgetary action to organisational and social perspectives.

Further research in this area, could examine more closely the cognitive, social, and external influences on the development of specific theory groups using the composite model. Sociometric analysis, which employs networks showing the social links among individuals over space and time, could be used to examine explicitly the crucial role played by social factors in the processes of theory group change. Additional key influences could be identified by a content analysis of the secondary literature, in particular, review articles. This secondary literature contains prominent participants' views concerning seminal works, key contributors, and intrusive external factors. In addition, the educational benefits to be derived from using a holistic graphic representation of knowledge, as provided by the empirical maps presented here, could be explored. Further research could also usefully be undertaken to update the analysis to cover the period from 1991 (during which time critical and interdisciplinary research expanded dramatically). 


\section{ENDNOTES}

1. An understanding of the development of scholarly accounting knowledge can also benefit non-accounting scholars. Accounting represents an important case study for those working in the field of scholarly knowledge development generally, since it possesses certain distinguishing characteristics whose impact has not been considered widely. In particular, accounting is an applied social science whose theory is embedded in other disciplines, such as economics, psychology, and sociology. In addition, the practice of accounting has professional status, and since the profession is largely self-regulated, research can fulfil a strategic role by representing an externally validated form of knowledge which may be used in the regulatory process. The accounting discipline therefore offers the opportunity to explore its relationships with related disciplines and its associated profession.

2. The three earlier approaches were the traditional philosophy of science (which emphasised internal cognitive factors); the sociology of knowledge (which emphasised external factors); and the sociology of science (which emphasised internal social factors).

3. Fogarty (2004: 37) observes that this domination is also reflected in the organization of the American Accounting Association.

4. Other writers (e.g., Merino, 1993) have focused upon the development of practical, rather than academic, accounting knowledge.

${ }^{5 .}$ Donaldson also argues for distinct stages in the 'life' of an idea. He likens major innovations to 'intellectual waves' and likens most academics to 'surfers' who 'mount and ride the crest until the wave loses its energy and breaks as a gentle ripple on the shore of established thought' (1977: 9). However, he notes that we are lucky if each decade has one or two 'waves'. An interesting empirical analysis would be to track the progress of specific waves. This would be complementary to the present paper's analysis, which reviews the entire 'sea'.

${ }^{6 .}$ Kuhn's view was that those who shared a disciplinary matrix shared the same 'way of seeing'.

7. A better description of this model might be the 'environmental determinism model', however the general usage term is employed here.

8. Murphy (1988) does acknowledge that Bourdieu's (1981) earlier analysis of scientific communities is wholly consistent with closure theory.

9. Citation analysis can be used for purposes other than the study of literature structure and research networks. For example, Brown (1996) identifies influential individuals and articles using citations from only five, predominantly North American, journals. However Shockley and Stratton (1995) are critical of using citations to evaluate individual faculty members for two main reasons. First, citations do not necessarily reflect 'value or quality', due to negative citations, self-citations and 'halo' effects. Second, the usefulness of a citation index based on a specific source journal set depends on its inclusiveness and representativeness.

10. In accounting, document co-citation analysis has been used to reveal the structure of individual research areas (Gamble and O’Doherty (1985) examine income smoothing and Gamble et al. (1987) examine agency theory).

11. The journal selections were influenced by comments from two anonymous reviewers and 
the editor.

12. The joint editors of the journal ( $\mathrm{T}$ Tinker and $\mathrm{D}$ Cooper) are based in the US and Canada, respectively. D Cooper originates from the UK.

13. The four journals in continued existence throughout the period represented all three key countries: Accounting Review, Journal of Accounting Research, Accounting and Business Research and Abacus.

14. For example, 'Beaver W' and 'Beaver WH' initially showed up as two distinct authors and had to be combined in the database.

15. Authors were excluded in period 1972-1981 if the either the number of zero co-citation counts exceeded 53 or the mean co-citation count was less than 6; authors were excluded in period 1982-19901 if the either the number of zero co-citation counts exceeded 15 or the mean co-citation count was less than 10. This difference in cut-off levels reflects the generally larger size of the database in the second period.

16. The 'elbow test' is a common heuristic used to determine the dimensionality of the data. Stress values are plotted against number of dimensions and joined up. If a noticeable 'elbow' occurs, this indicates that fit is not significantly improved by the addition of a further dimension. It is also recommended that stress values of 0.05 or less indicate a good fit (Kruskal and Wish, 1978:56). In both time periods, the elbow occurred at two dimensions and the stress value was less than 0.05 (0.037 and 0.045, respectively).

17. In agglomerative hierarchical clustering, each author starts as a cluster of one, and at each stage in the agglomeration process the closest two clusters join until all authors are in a single cluster. This process can be visually represented on a dendrogram, with large distances between stages indicating a high level of dissimilarity between the cluster pairs (Aldenderfer and Blashfield, 1984:53-57).

${ }^{18 .}$ It is interesting to speculate whether a map covering the previous ten years would locate these normative accounting theorists in a central position.

19. Green, who appears at the bottom of the generalist cluster (2b) was the founder editor of the Journal of Accounting Research, and authored several general papers on empirical research.

20. Although these three authors do form a cluster, it is so loosely connected and unfocussed that the boundary has not been shown. 
8

${ }^{9}$ An understanding of the development of scholarly accounting knowledge can also benefit nonaccounting scholars. Accounting represents an important case study for those working in the field of scholarly knowledge development generally, since it possesses certain distinguishing characteristics whose impact has not been considered widely. In particular, accounting is an applied social science whose theory is embedded in other disciplines, such as economics, psychology, and sociology. In addition, the practice of accounting has professional status, and since the profession is largely self-regulated, research can fulfil a strategic role by representing an externally validated form of knowledge which may be used in the regulatory process. The accounting discipline therefore offers the opportunity to explore its relationships with related disciplines and its associated profession. 


\section{REFERENCES}

AAA (1977) Statement on Accounting Theory and Theory Acceptance, (Sarasota, FL: American Accounting Association).

Aldenderfer, M.S. and R.K. Blashfield (1984) Cluster Analysis, No. 44 in Quantitative Applications in the Social Sciences Series, Beverly Hills, CA: Sage Publications).

Andrews, J.E. (2003) 'An author co-citation analysis of medical informatics', Journal of the Medical Library Association, 91(1), pp.47-56.

Barnes, B. (1977) Interests and the Growth of Knowledge, (London: Routledge \& Kegan Paul).

Barnes, B. (1982) T.S. Kuhn and Social Science, (London: Macmillan).

Bloor, D. (1976) Knowledge and Social Imagery, (London: Routledge \& Kegan Paul).

Baxter, W.T. (1988) Accounting Research - Academic Trends versus Practical Needs, (Edinburgh: Institute of Chartered Accountants on Scotland).

Beaver, W. (1981) Financial Reporting: An Accounting Revolution, (Englewood Cliffs, NJ: Prentice Hall).

Beaver, W. (1996) 'Directions in accounting research: NEAR and FAR', Accounting Horizons, 10(2), June, pp.113-124.

Beattie V. and A. Goodacre (2004) 'Publishing patterns within the UK accounting and finance academic community', British Accounting Review, 36(1), March, pp.7-44.

Beattie, V.A. and R.J. Ryan (1989) 'Performance indices and related measures of journal reputation in accounting', British Accounting Review, 21, pp. 267-278.

Beattie, V.A. and R.J. Ryan (1991) 'The impact of non-serial publications on research in accounting and finance’, Abacus, 27(1), pp. 32-50.

Borgman, C.L. (ed.) (1990) Scholarly Communication and Bibliometrics, (Newbury Park, CA: Sage Publications).

Bricker, R.J. (1988) 'Knowledge preservation in accounting: a citational study', Abacus, 24(2), September, pp. 120-131.

Bricker, R.J. and G.J. Previts (1990) 'The sociology of accountancy: a study of academic and practice community schisms’, Accounting Horizons, 4(1), March, pp. 1-14.

Bloom, R., H.G. Heymann, J. Fuglister and M. Collins (1994) The Schism in Accounting, Westpost, (CN: Quorum Books).

Bourdieu, P. (1981) 'The specificity of the scientific field', in C.C. Lemert (ed.), pp. 257-292 ,French Sociology: Rupture and Renewal since 1968, (Columbia University Press). 
Brown, L.D. (1996) 'Influential accounting articles, individuals, $\mathrm{PhD}$ granting institutions and faculties: a citational analysis,' Accounting, Organizations and Society, 21(7/8), pp. 723-54.

Brown, L.D. and J.C. Gardner (1985a) 'Using citation analysis to assess the impact of journals and articles on contemporary accounting research', Journal of Accounting Research, 23(1), Spring, pp. 84-109.

Brown, L.D. and J.C. Gardner (1985b) 'Applying citation analysis to evaluate the research contributions of accounting faculty and doctoral programs', The Accounting Review, 60(2), April, pp. 262-277.

Brown, L.D., J.C. Gardner and M.A. Vasarhelyi (1987) 'An analysis of the research contributions of Accounting, Organizations and Society, 1976-1984', Accounting, Organizations and Society, 12(2), pp. 193-204.

Brown, L.D., J.C. Gardner and M.A. Vasarhelyi (1989) 'Attributes of articles impacting contemporary accounting literature', Contemporary Accounting Research, 5(2), Spring, pp. 793-815.

Chambers, R.J. (1966) Accounting, Evaluation and Economic Behavior, (Englewood Cliffs, NJ: Prentice Hall).

Chua, W.F. (1986) 'Radical developments in accounting thought', The Accounting Review, 61(4), October, pp. 601-632.

Cleaver, K.C. and E.A. Evans (1991) 'Diverging views on the boundaries of management accounting: a growth of knowledge perspective', Management Accounting Research, 2, pp. 47-52.

Cole, J.R. and S. Cole (1973) Social Stratification in Science, (Chicago: University of Chicago Press).

Collins, R. (1979) The Credential Society: An Historical Sociology of Education and Stratification, (New York: Academic).

Cox, E.P., P.W. Hamelman and J.B. Wilcox (1976) 'Relational characteristics of business literature: an interpretive procedure’, Journal of Business, 49, April, pp. 252-265.

Crane, D. (1972) Invisible Colleges, (Chicago: University of Chicago Press).

Culnan, M.J. (1986) 'The intellectual development of management information systems, 19721982: a co-citation analysis’, Management Science, 32(2), February, pp. 156-172.

Culnan, M.J. (1987) 'Mapping the intellectual structure of MIS, 1980-1985: a co-citation analysis’, MIS Quarterly, 22, September, pp. 341-353.

Cushing, B.E. (1989) 'A Kuhnian interpretation of the historical evolution of accounting', The Accounting Historians Journal, 16(2), December, pp. 1-41. 
Davidson, S. (1984) 'The origins of the Journal of Accounting Research', Appendix to T.R. Dyckman and S.A. Zeff, 'Two decades of the Journal of Accounting Research', Journal of Accounting Research, 22(1), Spring, pp. 225-297.

Donaldson, G. (1977) 'Making intellectual waves’, Financial Management, 6(4), Winter, pp. 710.

Dyckman, T.R. (1989) 'Practice to research’, Accounting Horizons, 3, March, pp. 111-118.

Dyckman, T.R. and S.A. Zeff (1984) 'Two decades of the Journal of Accounting Research', Journal of Accounting Research, 22(1), Spring, pp. 225-297.

Edge, D.O. and M.J. Mulkay, (1976) Astronomy Transformed - The Emergence of Radio Astronomy in Britain, (London: John Wiley \& Sons).

Edwards, E.O. and P.W. Bell (1961) The Theory and Measurement of Business Income, (University of California Press).

Fogarty, T.J. (2004) 'Sustained research productivity in accounting: a study of the senior cohort', Global Perspectives on Accounting Education, 1, pp. 31-58.

Freidheim, E.A. (1978) 'A quantitative procedure for classifying the content of theory/research works’, The Sociological Quarterly, 19, Spring, pp. 234-252.

Gaffikin, M.J.R. (1988) 'Legacy of the golden age: recent developments in the methodology of accounting’, Abacus, 24(1), March, pp. 16-36.

Gaffikin, M.J.R. (2003) 'The a priori wars: the modernization of accounting thought', Accounting Forum, September, pp. 291-311.

Gamble, G.O. and B. O’Doherty (1985) 'How accounting academicians can use citation indexing and analysis for research', Journal of Accounting Education, 3(2), Fall, pp. 123-144.

Gamble, G.O., B. O’Doherty and L.M. Hyman (1987) 'The development of agency thought: a citation analysis of the literature', The Accounting Historians Journal, 14(1), Spring, pp. 7-26.

Garfield, E, (1979) Citation Indexing - Its Theory and Application in Science, Technology and Humanities, (New York: John Wiley \& Sons).

Glautier, M.W.E. (1983) 'Searching for accounting paradigms', The Accounting Historians Journal, Spring, pp. 51-68.

Gray, R. (1993) 'On collegiality and academic conversations: a valedictory editorial' British Accounting Review, 25(2), June, pp. 105-107.

Harre, R. (1986) Varieties of Realism, (Oxford: Basil Blackwell).

Hasselback, J.R., A. Reinstein and E.S. Schwan (2000) 'Benchmarks for evaluating the research productivity of accounting faculty', Journal of Accounting Education, 18(2), pp. 7997. 
Hopkins, F.L. (1984) 'New causal theory and ethnomethodology: citation patterns across a decade’, Scientometrics, 6(1), pp. 33-53.

Hopwood, A.G. (1992) Personal letter to the author.

Knorr-Cetina, K.D. and M. Mulkay (1983) 'Emerging principles in social studies of science' pp.1-17 in K.D. Knorr-Cetina and M. Mulkay (eds) Science Observed, (London: Sage Publications).

Kruskal, J.B. and M. Wish (1978) Multidimensional Scaling, No. 11 in Quantitative Applications in the Social Sciences Series, (Beverly Hills, CA: Sage Publications).

Kuhn, T.S. (1962) The Structure of Scientific Revolutions, (Chicago: University of Chicago Press).

Kuhn, T.S. (1970) The Structure of Scientific Revolutions, $2^{\text {nd }}$ edn, (Chicago: University of Chicago Press).

Laughlin, R.C. (1981) 'On the nature of accounting methodology' Journal of Business Finance and Accounting, 8(3), Autumn, pp. 329-351.

Lee, T.A. (1989) 'Education, practice and research in accounting: gaps, closed loops, bridges and magic accounting', Accounting and Business Research, 19(75), Summer, pp. 237-253.

Lee, T.A. (1990) 'A systematic view of the history of the world of accounting', Accounting, Business and Financial History, 1(1), October, pp. 73-107.

Lee, T.A. (1993) Cash Flow Reporting: A Recent History of An Accounting Practice, (New York: Garland Publishing).

Lee, T.A. (1997) 'The editorial gatekeepers of the accounting academy', Accounting, Auditing and Accountability Journal, 10(1), pp. 11-30.

Lievrouw, L.A. (1990) 'Reconciling structure and process in the study of scholarly communication', pp.59-68 in C.L. Borgman (ed.) Scholarly Communication and Bibliometrics, (Newbury Park, CA: Sage Publications).

Lowe, E.A., A.G. Puxty and R.C. Laughlin (1983) 'Simple theories for complex processes: accounting policy and the market for myopia', Journal of Accounting and Public Policy, 2, pp. 19-42.

Lukka, K. and E. Kasanen (1996) 'Is accounting a global or a local discipline? Evidence from major research journals', Accounting, Organizations and Society, 21(7/8), pp. 755773.

MacKenzie, D. (1981) Statistics in Britain 1865-1930: The Social Construction of Scientific Knowledge, (Edinburgh: Edinburgh University Press).

Masterman, M. (1970) 'The nature of the paradigm', pp.59-89, in Criticism and the Growth of Knowledge, I. Lakatos and A. Musgrave (eds.), (Cambridge: Cambridge University 
Press).

Mattessich, R. (1991) Accounting Research in the 1980s and its Future Relevance, (Vancouver: The Canadian Certified General Accountants’ Research Foundation).

McCain, K.W. (1983) 'The author cocitation structure of macroeconomics', Scientometrics, 5, pp. 277-289.

McCain, K.W. (1984) 'Longitudinal author cocitation mapping: the changing structure of macroeconomics', Journal of the American Society for Information Science, 35(6), pp. 351-359.

McCain, K.W. (1986) 'The paper trails of scholarship: mapping the literature of genetics', Library Quarterly, 56(3), pp. 258-271.

McCain, K.W. (1990) 'Mapping authors in intellectual space: a technical overview', Journal of the American Society for Information Science, 41(6), pp. 433-443.

McRae, T.W. (1974) 'A citational analysis of the accounting information network', Journal of Accounting Research, 12(1), Spring, pp. 80-92.

Merino, B.D. (1993) 'An analysis of the development of accounting knowledge: a pragmatic approach', Accounting, Organizations and Society, 18(2/3): 163-185.

Merton, R.K. (1973) The Sociology of Science, University of Chicago Press.

Mouck, T. (1993) `The "revolution” in financial reporting theory: a Kuhnian interpretation', The Accounting Historians Journal, 20(1), June, pp. 33-57.

Mulkay, M.J. (1975) 'Three models of scientific development', Sociological Review, pp. 510537.

Mulkay, M.J. (1979) Science and the Sociology of Knowledge, (London: Allen and Unwin).

Mulkay, M.J., G.N. Gilbert and S. Woolgar (1975) 'Problem areas and research networks in science', Sociology, 9, pp. 187-203.

Mullins, N.C. (1973) Theories and Theory Groups in Contemporary American Sociology, (New York: Harper and Row).

Murphy, R. (1988) Social Closure, (Oxford: Clarendon Press).

Nelson, C.L. (1973) ‘A priori research in accounting’, pp.3-19 in N. Dopuch and L. Revsine (eds) Accounting Research 1960-1970: A Critical Evaluation, (Centre for International Education and Research in Accounting, University of Illinois).

Parkin, F. (1974) 'Strategies of social closure in class formation', pp.1-18 in F. Parkin (ed.) The Social Analysis of Class Structure, (London: Tavistock).

Paton, W.A. and A.C. Littleton (1940) An Introduction to Corporate Accounting Standards, (Sarasoto, FL: American Accounting Association). 
Peasnell, K.V. (1978) 'Statement of Accounting Theory and Theory Acceptance: a review article’, Accounting and Business Research, 9(31), Summer, pp. 217-225.

Peasnell, K.V. and D.J. Williams (1986) 'Ersatz academics and scholar-saints: the supply of financial accounting research’, Abacus, 22(2), September, pp. 121-135.

Peterson, G.L. (1981) 'Historical self-understanding in the social sciences: the use of Thomas Kuhn in psychology', Journal of Theory and Social Behaviour, 11(1), pp. 1-30.

Previts, G.J., L.D. Parker and E.N. Coffman (1990) 'An accounting historiography: subject matter and methodology’, Abacus, 26(2), September, pp. 136-158.

Price, D.J. (1961) Science Since Babylon, (Yale University Press).

Price, D.J. (1963) Little Science, Big Science, (Yale University Press).

Ryan B., R.W. Scapens and M. Theobald (1994) Research Method and Methodology in Finance and Accounting, (London: Academic Press).

Shockley, R.A. and R Stratton (1995) 'An assessment of citation analysis as a generalized tool for measuring individual research productivity,' Accounting Perspectives, Fall, pp. 1-18.

Small, H.G. (1973) 'Co-citation in the scientific literature: a new measure of the relationship between two documents', Journal of the American Society for Information Science, 24, pp. 265-269.

Small, H.G. and B.C. Griffith (1974) 'The structure of scientific literature, 1: identifying and graphing specialties’, Science Studies, 4, pp. 17-40.

Watts, R.L. and J.L. Zimmerman (1979) 'The demand for and supply of accounting theories: the market for excuses’, The Accounting Review, 54(2), April, pp. 273-305.

Wells, M.C. (1976) 'A revolution in accounting thought?', The Accounting Review, 51(3), July, pp. 471-482.

White, H.D. (1981) 'Cocited author retrieval online: an experiment with the social indicators literature’, Journal of the American Society for Information Science, 32, pp. 16-21.

White, H.D. (1983) 'A cocitation map of the social indicators movement', Journal of the American Society for Information Science, 34(5), pp. 307-312.

White, H.D. (1986) 'Cocited author retrieval', Information Technologies and Libraries, 5, June, pp. 93-99.

White, H.D. (1990) 'Author co-citation analysis: overview and defense', pp. 84-106 in C.L. Borgman (ed.), Scholarly Communication and Bibliometrics, (Newbury Park, CA: Sage Publications).

White, H.D. and B.C. Griffith (1981a) 'Author cocitation: a measure of intellectual structure’, 
Journal of the American Society for Information Science, 32(3), pp. 163-171.

White, H.D. and B.C. Griffith (1981b) 'A cocitation map of authors in judgment and decision research', pp.261-272 in B.F. Anderson, D.H. Deane, K.R. Hammond and G.H. McClelland (eds) Concepts in Judgment and Decision Research: Definitions, Sources, Interrelations, Comments, (New York: Preager).

White, H.D. and B.C. Griffith (1982) 'Authors as markers of intellectual space: co-citation in studies of science, technology and society', Journal of Documentation, 38(4), pp. 255272.

White, H.D. and K.W. McCain (1998) 'Visualising a discipline: an author co-citation analysis of information science, 1972-1995', Journal of the American Society for Information Science, 49(4), pp.327-355.

Williams, P.F. (2003) 'Modern accounting scholarship: the imperative of positive economic science', Accounting Forum, 27(3), September, pp. 251-269.

Woolgar, S. (ed.) (1988) Knowledge and Reflexivity: New Frontiers in the Sociology of Knowledge, (Beverly Hills, CA: Sage Publications).

Zeff, S.A. (1996) 'A study of academic research journals in accounting', Accounting Horizons, 10(3), pp.158-177. 


\section{Eigure 1: Primary Emphases of Models of Scholarly Knowledge Development}

\begin{tabular}{|c|c|c|c|c|c|}
\hline \multirow{2}{*}{\multicolumn{2}{|c|}{ Aspects of Development }} & \multicolumn{4}{|c|}{ Model of Scholarly Knowledge Development } \\
\hline & & $\begin{array}{l}\text { Four stage } \\
\text { (Mullins) }\end{array}$ & $\begin{array}{l}\text { Branching } \\
\text { (Mulkay) }\end{array}$ & $\begin{array}{c}\text { Interest } \\
\text { (Barnes/Bloor) }\end{array}$ & $\begin{array}{c}\text { Closure } \\
\text { (Murphy) }\end{array}$ \\
\hline \multirow[t]{3}{*}{ Source of change: } & :internal cognitive & $*$ & * & & \\
\hline & :internal social & * & * & & \\
\hline & :external & & & * & \\
\hline \multirow[t]{3}{*}{ Stage of change } & :formation & & $*$ & & \\
\hline & :growth & $*$ & & & \\
\hline & :closure & & $*$ & & $*$ \\
\hline \multirow[t]{2}{*}{ Process of change } & :comparative-static & $*$ & & & \\
\hline & :dynamic & & & & $*$ \\
\hline
\end{tabular}


Figure 2: An Author Co-citation Map of the Accounting Literature, 1972-81

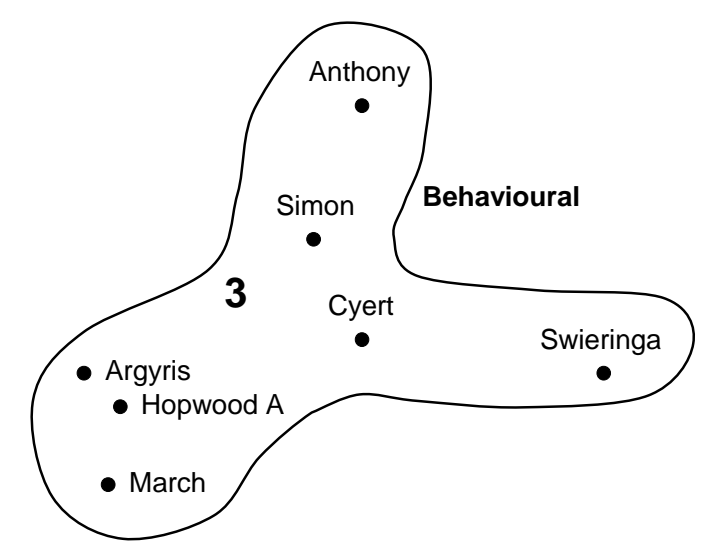

Psychology /

Oraanicational thenry

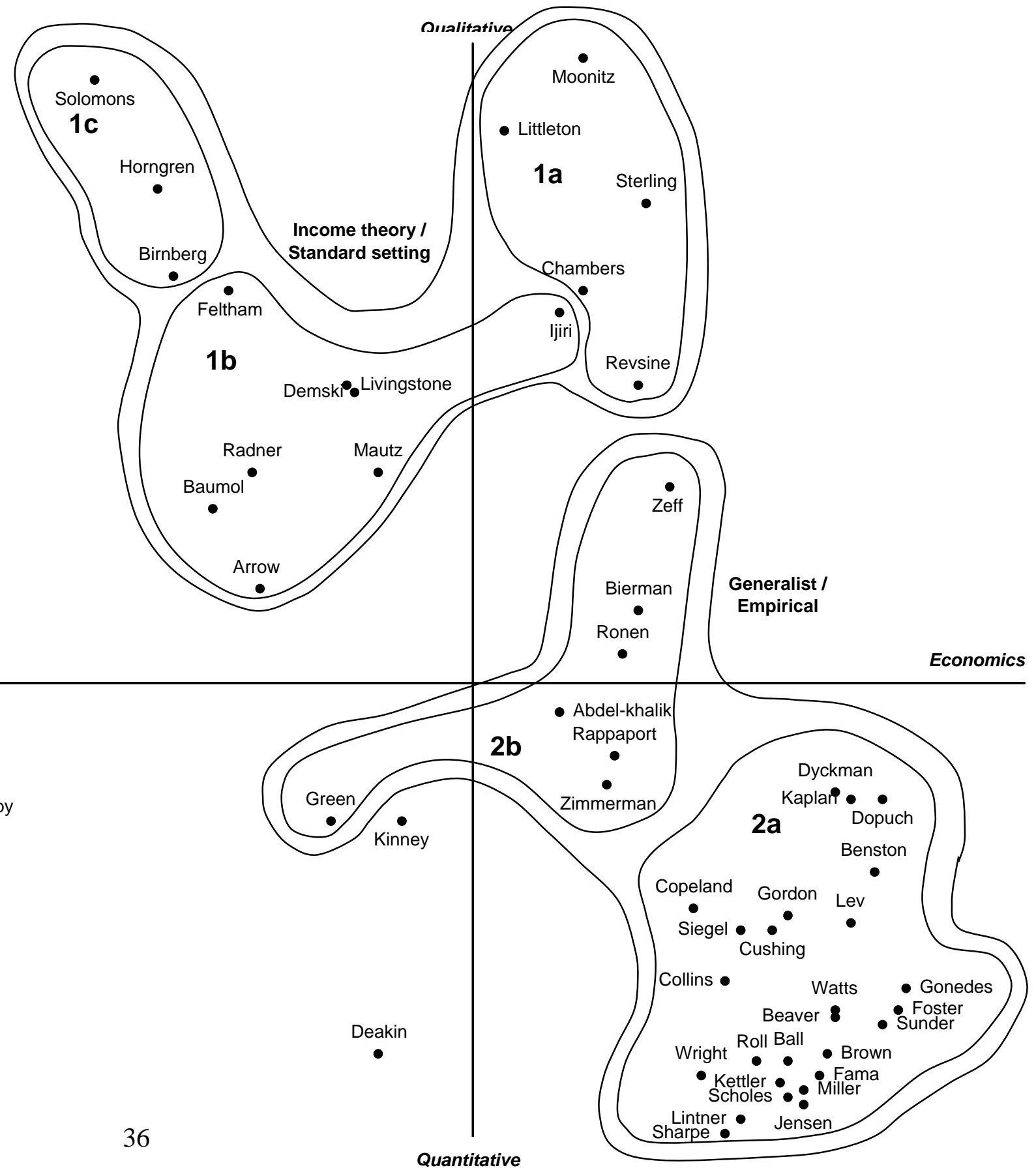


Figure 3: An Author Co-citation Map of the Accounting Literature, 1982-90
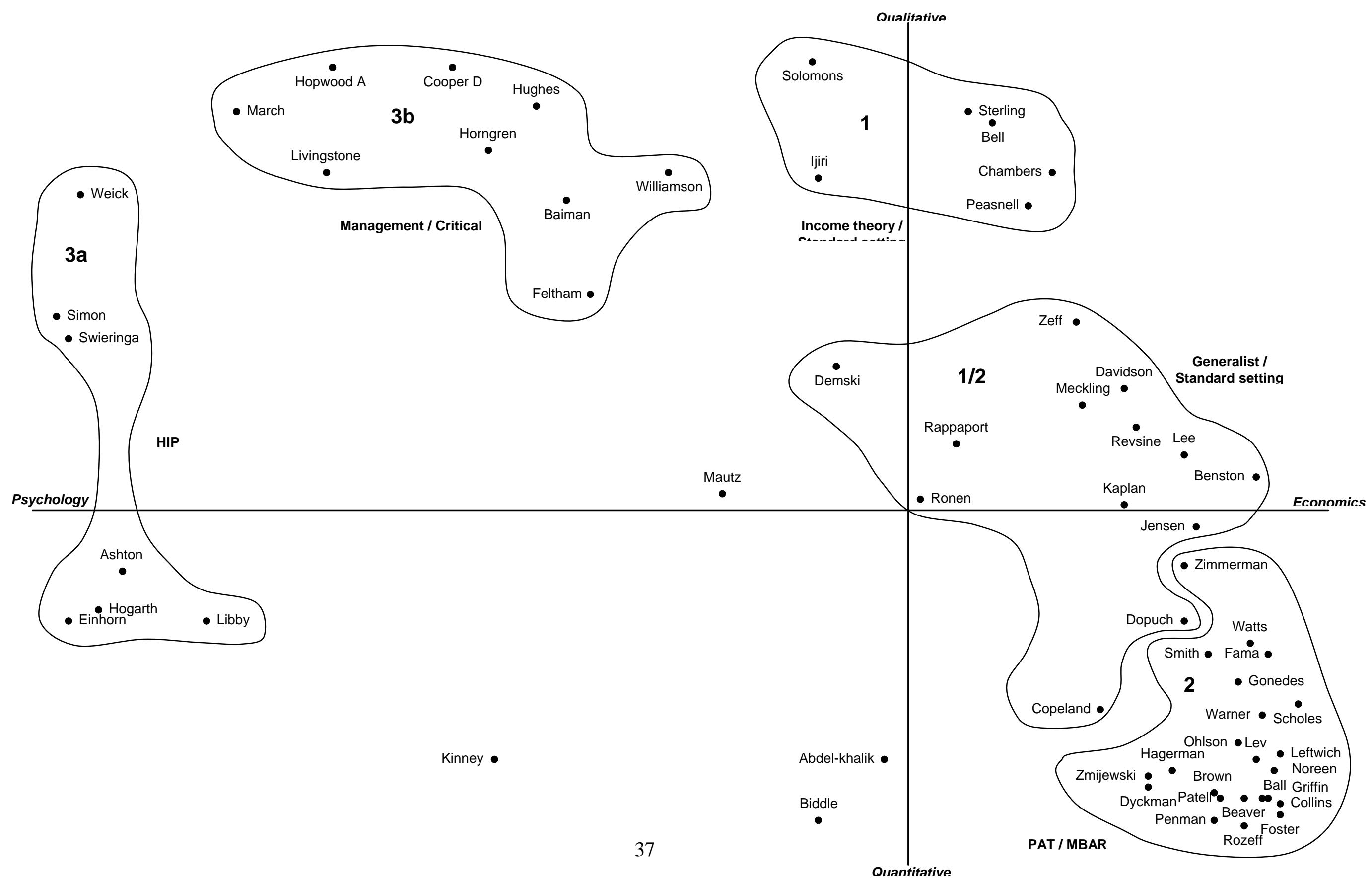
Table 1: Key Features of Selected Journals and Number of Papers Analysed

\begin{tabular}{|l|l|l|l|l|l|}
\hline \multicolumn{1}{|c|}{ Journal } & Start & Characterisation of & \multicolumn{1}{c|}{$\begin{array}{c}\text { No.of } \\
\text { papers } \\
\text { analysed } \\
\text { jear }\end{array}$} & $\begin{array}{c}\text { No.of } \\
\text { journal focus } \\
\text { papers } \\
\text { analysed } \\
\mathbf{1 9 8 2 - 1 9 9 0}\end{array}$ & $\begin{array}{c}\text { Total } \\
\text { no.of } \\
\text { papers } \\
\text { analysed }\end{array}$ \\
\hline Accounting Review & 1926 & Generalist & 661 & 417 & 1078 \\
\hline Journal of Accounting Research & 1963 & Empirical research & 454 & 390 & 844 \\
\hline $\begin{array}{l}\text { Journal of Accounting and } \\
\text { Economics }\end{array}$ & 1979 & $\begin{array}{l}\text { Positive accounting } \\
\text { theory }\end{array}$ & 27 & 142 & 169 \\
\hline $\begin{array}{l}\text { Accounting and Business } \\
\text { Research }\end{array}$ & 1970 & Generalist & 322 & 322 & 644 \\
\hline $\begin{array}{l}\text { Journal of Business Finance and } \\
\text { Accounting }\end{array}$ & 1974 & Generalist & 306 & 412 & 718 \\
\hline $\begin{array}{l}\text { Accounting, Organizations and } \\
\text { Society }\end{array}$ & 1976 & Behavioural & 161 & 299 & 460 \\
\hline Abacus & 1965 & Generalist & 131 & 120 & 251 \\
\hline $\begin{array}{l}\text { Accounting, Auditing and } \\
\text { Accountability Journal }\end{array}$ & 1988 & Interdisciplinary & 0 & 33 & 33 \\
\hline $\begin{array}{l}\text { Critical Perspectives on } \\
\text { Accounting }\end{array}$ & 1990 & Critical & 0 & 14 & 14 \\
\hline & & & 2062 & 2149 & 4211 \\
\hline
\end{tabular}


Table 2: Author Sets Included in the Co-Citation Analysis

\begin{tabular}{|l|l|l|l|}
\hline Abdel-khalik AR & Davidson S** & Kettler P* & Revsine L \\
\hline Anthony RN* & Deakin EB* & Kinney WR & Roll R* \\
\hline Argyris C* & Demski JS & Lee TA** & Ronen J \\
\hline Arrow KJ* & Dopuch N & Leftwich RW** & Rozeff MS** \\
\hline Ashton RH** & Dyckman TR & Lev B & Scholes MS \\
\hline Baiman S** & Einhorn HJ** & Libby R & Sharpe W* \\
\hline Ball RJ & Fama EF & Lintner J* & Siegel S* \\
\hline Baumol WJ* & Feltham GA & Littleton AC* & Simon HA \\
\hline Beaver WH & Foster G & Livingstone JL & Smith CW** \\
\hline Bell PW** & Gonedes NJ & March JG & Solomons D \\
\hline Benston GJ & Gordon MJ* & Mautz RK & Sterling RR \\
\hline Biddle GC** & Green D* & Meckling WH** & Sunder S* \\
\hline Bierman H* & Griffin PA** & Miller MH* & Swieringa RJ \\
\hline Birnberg JG* & Hagerman RL** & Moonitz M* & Warner JB** \\
\hline Brown P & Hogarth RM** & Noreen EW** & Watts RW \\
\hline Chambers RJ & Hopwood AG & Ohlson JA** & Weick KE** \\
\hline Collins DW & Horngren CT & Patell JM** & Williamson OE $* *$ \\
\hline Cooper DJ** & Hughes J** & Peasnell KV** & Wright WF* \\
\hline Copeland RM & Ijiri Y & Penman SH** & Zeff SA \\
\hline Cushing BE* & Jensen MC & Radner R* & Zimmerman JL \\
\hline Cyert RM* & Kaplan RS & Rappaport A & Zmijewski ME** \\
\hline
\end{tabular}

* Member of author set for 1972-1981 period only.

** Member of author set for 1982-1990 period only. 